\title{
Vitamin D Deficiency in Guinea Pigs: Exacerbation of Bone Phenotype During Pregnancy and Disturbed Fetal Mineralization, with Recovery by $1,25(\mathrm{OH})_{2} \mathrm{D}_{3}$ Infusion or Dietary Calcium-Phosphate Supplementation
}

\author{
K. Rummens, ${ }^{1}$ R. van Bree, ${ }^{1}$ E. Van Herck, ${ }^{2}$ Z. Zaman, ${ }^{3}$ R. Bouillon, ${ }^{2}$ F.A. Van Assche, ${ }^{1}$ J. Verhaeghe ${ }^{1,2}$ \\ ${ }^{1}$ Department of Obstetrics and Gynecology, Katholieke Universiteit Leuven, 3000 Leuven, Belgium \\ ${ }^{2}$ Laboratorium voor Experimentele Geneeskunde en Endocrinologie, Katholieke Universiteit Leuven, 3000 Leuven, Belgium \\ ${ }^{3}$ Department of Laboratory Medicine, Katholieke Universiteit Leuven, 3000 Leuven, Belgium
}

Received: 9 November 2001 / Accepted: 15 March 2002 / Online publication: 29 August 2002

Abstract. Vitamin D (D) deficiency during human pregnancy appears to disturb fetal growth and mineralization, but fetal development is normal in D-deficient rats and vitamin D receptor gene-ablated mice. We used the guinea pig model to investigate maternal and fetal effects of D deficiency. Pregnant (Pr) and nonpregnant (NPr) animals were fed a D-replete (+D) or D-deficient diet $(-D)$ for 8 weeks. We further studied whether the effects of a $-\mathrm{D}$ diet are reversed by continuous $1,25(\mathrm{OH})_{2} \mathrm{D}_{3}$ infusion $(-\mathrm{D}+1,25)$ and/or by a lactose-, $\mathrm{Ca}-$ and $\mathrm{P}$-enriched D-deficient $\operatorname{diet}(-\mathrm{D}+\mathrm{Ca} / \mathrm{P})$. Bone analyses included histomorphometry of the proximal tibiae, dual-energy X-ray absorptiometry (DXA), and quantitative computed tomography (QCT) of the femora. Depletion of $25(\mathrm{OH}) \mathrm{D}_{3}$ and $1,25(\mathrm{OH})_{2} \mathrm{D}_{3}$ levels and the D-deficiency syndrome were more severe in pregnant animals. Indeed, $\operatorname{Pr} /-\mathrm{D}$ but not $\mathrm{NPr} /-\mathrm{D}$ guinea pigs were hypophosphatemic, and showed robust increases in growth plate width and osteoid surface and thickness; in addition, bone mineral density on DXA was lower in $\operatorname{Pr} /-\mathrm{D}$ animals only, which was exclusively in cortical bone on QCT. Bone phenotype was partly normalized in $\operatorname{Pr} /-\mathrm{D}+1,25$ and $\operatorname{Pr} /-\mathrm{D}+\mathrm{Ca} / \mathrm{P}$ animals. Compared with $+\mathrm{D}$ fetuses, $-\mathrm{D}$ fetuses had very low or undetectable $25(\mathrm{OH}) \mathrm{D}_{3}$ and $1,25(\mathrm{OH})_{2} \mathrm{D}_{3}$, were hypercalcemic and hypophosphatemic, and had lower osteocalcin levels. In addition, body weight and total body bone mineral content were 10-15\% lower; histomorphometry showed hypertrophic chondrocyte zone expansion and hyperosteoidosis. $1,25(\mathrm{OH})_{2} \mathrm{D}_{3}$ levels were restored in $-\mathrm{D}+1,25$ fetuses, and the phenotype was partially corrected. Similarly, the fetal $+\mathrm{D}$ phenotype was rescued in large part in $-\mathrm{D}+\mathrm{Ca} / \mathrm{P}$ fetuses, despite undetectable circulating $25(\mathrm{OH}) \mathrm{D}_{3}$ and $1,25(\mathrm{OH})_{2} \mathrm{D}_{3}$. We conclude that pregnancy markedly exacerbates $\mathrm{D}$

Correspondence to: K. Rummens; e-mail: katrien.rummens @) uz.kuleuven.ac.be deficiency, and that augmenting $\mathrm{Ca}$ and $\mathrm{P}$ intake overrides the deleterious effects of $\mathrm{D}$ deficiency on fetal development.

Key words: Vitamin D deficiency - Guinea pig Pregnancy - Fetal mineralization - Histomorphometry.

$\mathrm{D}$ deficiency is common in women during the reproductive period and pregnancy. A report of a high prevalence of Ddeficiency in pregnant Asian women living in Britain [1] has been followed by the recognition that $\mathrm{D}$ deficiency is also common in women of reproductive age in more southern regions with abundant sunlight [2-5]. Avoidance of ultravioltet (UV) light exposure - by wearing traditional dress and staying indoors - appears to be the primary risk factor $[4,5]$, with lower dietary $\mathrm{D}$ intake as a secondary factor $[5,6]$.

In humans, there is fragmentary evidence that D deficiency disturbs fetal development. Cases of 'fetal rickets' have been reported in severely D-deficient pregnant women [7]. Babies of D-deficient mothers were found to be more frequently small-for-gestational age [1], and their birth length was correlated with maternal ionized calcium $\left(\mathrm{Ca}^{2+}\right)$ levels [8]. Vitamin D supplements during the third trimester of pregnancy increased birth weight in Asian women [9]. Also, cord plasma alkaline phosphatase levels were raised in D-deficient pregnancies, the newborns had a larger anterior fontanelle, and symptomatic early neonatal hypocalcemia was more common [1]. Furthermore, total-body bone mineral content (BMC) was $6 \%$ lower in winter-born than in summer-born newborns in South Korea, and was correlated with cord serum 25-hydroxyvitamin $\mathrm{D}_{3}$ [25(OH) $\mathrm{D}_{3}$ ] levels [10].

Studies in small rodents failed to show an effect of $\mathrm{D}$ deficiency on fetal growth and mineralization. In D-deficient rats, fetal body weight and $\mathrm{Ca}$ content/ 
weight [11], trabecular bone volume on tibial histomorphometry [12] and plasma $\mathrm{Ca}$ and phosphate (P) levels [13] were found to be normal, although there was a significant increase in osteoid area [12]. In fact, when corrected for lower milk intake, D deficiency did not affect growth and mineralization until day 20 of postnatal life [14]. Similarly, growth, bone histology, and plasma $\mathrm{Ca}$ and parathyroid hormone (PTH) levels were normal before postnatal day 21 in mice with a vitamin $D$ receptor (VDR) gene knockout; however, an expansion in the hypertrophic chondrocyte width was observed by day $15[15,16]$.

Fetuses of small rodents are born chemically and physiologically immature, and growth and bone formation increase rapidly during the suckling and early postweaning stages [17]. In contrast, guinea pig fetuses (gestation length 63-68 days) are mineralized comparably to human fetuses by the end of gestation, and show active bone formation [18]. Herein we examined the effects of a D-deficient diet in guinea pigs on maternal and fetal bone and mineral metabolism. The diet was started on the first day of pregnancy to avoid infertility [19]; we also studied nonpregnant guinea pigs fed the diet during a similar period of 8 weeks. Also, we studied the effect of maternal treatment with 1,25-dihydroxyvitamin $\mathrm{D}_{3}$ $\left[1,25(\mathrm{OH})_{2} \mathrm{D}_{3}\right]$, the only vitamin $\mathrm{D}$ metabolite required to prevent rickets in postnatal rats fed a D-deficient diet [20]. We used a dose ( $5 \mathrm{ng} / 100 \mathrm{~g} / \mathrm{day}$, s.c.) that was shown to maximally prevent rickets in D-deficient rats; indeed, at higher doses, $1,25(\mathrm{OH})_{2} \mathrm{D}_{3}$ may induce, rather than reverse, osteomalacia [21]. $1,25(\mathrm{OH})_{2} \mathrm{D}_{3}$ crosses the placental barrier in humans [22], and we have reported a highly significant correlation between maternal and fetal $1,25(\mathrm{OH})_{2} \mathrm{D}_{3}$ levels in humans [23], guinea pigs [24], and rats $[25] .1,25(\mathrm{OH})_{2} \mathrm{D}_{3}$ treatment was given during the last 4 weeks of pregnancy only, since ossification centers are first detected from fetal day 26 in guinea pigs [26]. Finally, we studied the effect of a high lactose, Ca- and Penriched D-deficient diet. A comparable diet reduced or even normalized the secondary hyperparathyroidism and the skeletal abnormalities (rickets and osteomalacia) in weaned nutritionally D-deficient rats $[27,28]$ as well as in weaned mice with an ablated VDR gene [29, 30].

\section{Materials and Methods}

\section{Animals}

All experiments were approved by the ethical committee for animal research at the K.U. Leuven. Two- to three-month-old (young adult) female guinea pigs, bred at the K.U. Leuven Proefdierencentrum, were housed in a room with a constant temperature of $22^{\circ} \mathrm{C}$ and a 12 hour light/12 hour dark cycle. All animals were fed a standard guinea-pig chow ad libitum, containing $0.96 \% \mathrm{Ca}, 0.49 \% \mathrm{P}, 2400 \mathrm{IU}$ vitamin $\mathrm{D}_{3} / \mathrm{kg}$, and $1600 \mathrm{mg}$ vitamin $\mathrm{C} / \mathrm{kg}$ (Hope Farms, Woerden, the Netherlands). The animals received deionized water with added vitamin $\mathrm{C}(400 \mathrm{mg} / \mathrm{L})$, as guinea pigs are susceptible to de- velopment of vitamin $\mathrm{C}$ deficiency. Part of the animals were mated during the day; the presence of a copulation plug was checked twice daily on those days. Once a vaginal plug was detected, the animal was kept in a separate cage and labeled; this day was defined as day 1 of pregnancy. The pregnant animals were divided into four experimental groups: (1) a Dreplete group ( $+\mathrm{D}$ group), which continued on the standard guinea pig diet; (2) a D-deficient group (-D group), fed an experimental diet containing $0.97 \% \mathrm{Ca}, 0.38 \% \mathrm{P}$, no vitamin $\mathrm{D}_{3}$, and $2300 \mathrm{mg}$ vitamin $\mathrm{C} / \mathrm{kg}$ (Harlan/Teklad, Zeist, the Netherlands); (3) a D-deficient group, which were infused s.c. with $1,25(\mathrm{OH})_{2} \mathrm{D}_{3}(0.12 \mathrm{nmol} /$ day $)$ via an Alzet miniosmotic pump (model 2ML4, Charles River, Palo Alto, CA) placed in the back region under anesthesia (ketamine hydrochloride, 48 $\mathrm{mg} / \mathrm{kg}$, and xylazine hydrochloride, $6 \mathrm{mg} / \mathrm{kg}$, both i.m.) from day 30 of pregnancy onward ( $-\mathrm{D}+1,25$ group); (4) a D-deficient group fed an experimental diet containing $20 \%$ lactose as carbohydrate, $1.9 \% \mathrm{Ca}, 1.0 \% \mathrm{P}$, and $2300 \mathrm{mg}$ vitamin $\mathrm{C} / \mathrm{kg}$ (Harlan/Teklad) $(-\mathrm{D}+\mathrm{Ca} / \mathrm{P}$ group). All animals in groups $2-4$ were housed in a UV light-free room. The experimental diets in groups 2-4 were introduced over a 7-day period, in a $50 \%$ standard-50\% experimental diet mixture, to avoid food deprivation; the experimental diet was then continued for 7 weeks. Nonpregnant animals received the experimental diets for the same duration. All animals received fluorochrome labeling with calcein (Sigma, St. Louis, MO), $16 \mathrm{mg} / \mathrm{kg}$ i.m., 8 days and 1 day (24 hours) prior to the end of the study.

Eight weeks after the start of the experiment (day 57 for pregnant animals), the animals were transported to the UV light-deprived surgical room, and were anesthetized as described. The anesthetized animals were weighed, and xylocaine $2 \%$ was injected s.c. in the midline abdominal area, prior to laparotomy. In pregnant animals, the uterus was exposed, and amniotic fluid was collected from the gestational sacs and pooled. The fetuses were exposed through a small uterine incision from left to right, and a midline laparotomy was performed in each fetus to obtain a blood sample from the abdominal aorta, with the umbilical cord still attached to the placenta. All fetuses and placentas were weighed. The sample from the last exposed fetus was kept for measurement of $\mathrm{Ca}^{2+}$, total $\mathrm{Ca}$, and $\mathrm{P}$; the previous samples were kept for measurement of $25(\mathrm{OH}) \mathrm{D}_{3}, 1,25(\mathrm{OH})_{2} \mathrm{D}_{3}$, and osteocalcin. The last two fetuses (or last fetus in case there were only two fetuses per mother) were eviscerated, weighed again, and stored at $-20^{\circ} \mathrm{C}$ for measurement of whole body BMC. The tibiae were removed from the other fetuses for histomorphometry. A blood sample was taken from the abdominal aorta of the mother, and the animal was euthanized by cervical dislocation. Both tibiae were removed for histomorphometry and both femora were removed for measurement of weight and dual-energy X-ray absorptiometry (DXA) and peripheral quantitative computed tomography (PQCT) analysis. The surgical procedure did not exceed $45 \mathrm{~min}$; the $\mathrm{Ca}^{2+}$ measurements were done within $10 \mathrm{~min}$ of the maternal sample collection.

Assays

All assays, except $\mathrm{Ca}^{2+}$ and $1,25(\mathrm{OH})_{2} \mathrm{D}_{3}$, were done in a single run. $\mathrm{Ca}^{2+}$ was measured in whole blood by the ion selective electrode method on the Ciba Corning 288 Blood Gas System (Bayer Diagnostics, Brussels, Belgium); plasma P was measured by colorimetry [31]. Plasma $25(\mathrm{OH}) \mathrm{D}_{3}$ was measured by direct competitive protein binding assay [32]; the detection limit of this assay is about $2.5 \mu \mathrm{g} / \mathrm{L}(6.25 \mathrm{nmol} / \mathrm{L})$. Plasma $1,25(\mathrm{OH})_{2} \mathrm{D}_{3}$ was measured by radioimmunoassay (RIA) after HPLC purification, as described [23], with later modifications [31]; the detection limit is around $18 \mathrm{pg}$ for $1 \mathrm{~mL}$ plasma (43 pmol/L). Vitamin D-binding protein (DBP) was measured by a single radial immunodiffusion assay specific for guinea pig DBP [18]; the free $1,25(\mathrm{OH})_{2} \mathrm{D}_{3}$ index was calculated as the $1,25(\mathrm{OH})_{2} \mathrm{D}_{3} / \mathrm{DBP}$ molar index $\left(\times 10^{-5}\right)[23]$. Plasma osteocalcin was measured by RIA with guinea pig osteocalcin as the standard and a rabbit polyclonal antiserum 
[18]. Amniotic fluid deoxypyridinoline, which was used as a measure of fetal bone resorption, was measured fluorometrically after acid hydrolysis, extraction, and HPLC separation, as described previously; values were corrected for creatinine concentrations [33].

\section{Bone Studies}

Wet and dry weights were obtained for all femora; to obtain dry weights, bones were dried in ethanol and diethylether $(1 / 1$, $\mathrm{vol} / \mathrm{vol}$ ) and then diethylether.

$D X A$ was performed on both adult femora and on whole fetuses using a Hologic QDR-1000 absorptiometer (Waltham, MA), as described previously [24, 34]. For the adult femora, we measured the BMC and bone mineral density (BMD) of the whole femur, of a mid-diaphyseal area consisting exclusively of cortical bone, and of a metaphyseal area at $20 \%$ from the distal end of the femur consisting of both trabecular and cortical bone. The coefficient of variation (CV) of 8 consecutive measurements of adult femora was $0.8 \%$ for the whole femur $\mathrm{BMD}, 1.7 \%$ for the mid-diaphyseal BMD, and $2.1 \%$ for the metaphyseal BMD. The CV of 10 consecutive measurements of whole fetus BMC was $4.7 \%$.

$P Q C T$ was performed on adult and fetal femora using a XCT Bone Scanner (Norland, Fort Atkinson, WI) and software 5.40 . Slices were $0.3 \mathrm{~mm}$ thick, and voxel size was 0.07 $\mathrm{mm}$. Trabecular bone density was measured in an inner area of $25 \%$ of the total cross-sectional area, at 3,4 , and $5 \mathrm{~mm}$ from the distal growth plate in the adult femora, and at $4.25,4.5$, and $4.75 \mathrm{~mm}$ from the distal end of the femur in the fetuses. Cortical bone density was measured at $15 \mathrm{~mm}$ from the distal growth plate in the adult femora, and at $10 \mathrm{~mm}$ from the distal end of the femora in the fetuses. Between-measurement CV was $<1 \%$.

Histomorphometry of adult and fetal proximal tibiae was performed as described previously [24, 34], using the nomenclature proposed by Parfitt et al. [35]. The undecalcified left proximal tibia was embedded in methylmetacrylate, and $4 \mu \mathrm{m}-$ thick longitudinal sections were cut. Three sections were measured per animal, with $800 \mu \mathrm{m}$ in between. Static and dynamic morphometry were performed using a VIDAS 21 Image Analyzing Computer (Kontron, Munich, Germany) or a KS 100 Image Analyzing Computer (Carl Zeiss, Hallbergmoos, Germany). We used von Kossa-stained sections for the measurement of trabecular bone volume (BV/TV), sections stained with a modified Goldner-trichrome for the measurement of osteoid surface (OS/BS), and osteoid thickness and the growth plate width, and unstained sections for the fluoromicroscopic measurement of double- and single-labeled surfaces (dLS/BS and sLS/BS, respectively), and the mineral apposition rate (MAR). In adult tibiae, growth plate width was measured over the full length of the growth plate at $\times 150$ magnification. $\mathrm{BV} / \mathrm{TV}$ was measured in 4 consecutive fields in the vertical axis of the central metaphysis at $\times 150$ magnification, excluding the primary spongiosa (i.e., starting at $1 \mathrm{~mm}$ from the distal growth plate). The other measurements were performed in the secondary spongiosa, in as many fields as possible, excluding the endocortical and subcortical bone surfaces: $37 \pm 1$ fields (mean \pm SEM, $n=180$ ) were assessed per section, corresponding to $38,960 \pm 1,197 \mu \mathrm{m}$ trabecular bone surface. For dynamic morphometry, we measured $101 \pm 14$ double labels per section; the MAR was measured at 3 equidistant points per double label. The mineral formation rate, surface-referent (MFR/BS), was calculated as the mineralizing surface (MS/BS $=\mathrm{dLS} / \mathrm{BS}+1 / 2 \mathrm{sLS} / \mathrm{BS}) *$ MAR $* \pi / 4$. In fetal tibiae, growth plate width could not be measured because there was a variable degree of growth plate ossification. We therefore measured the area occupied by hypertrophic chondrocytes relative to the total chondrocyte area of the growth plate (calculated as a \%), at $\times 75$ magnification. Dynamic morphometry could not be performed in sections from fetal tibiae because the fluorochrome labeling - though abundant - was patchy. OS/BS and O.Th. at the trabecular bone surface were measured at $\times 300$
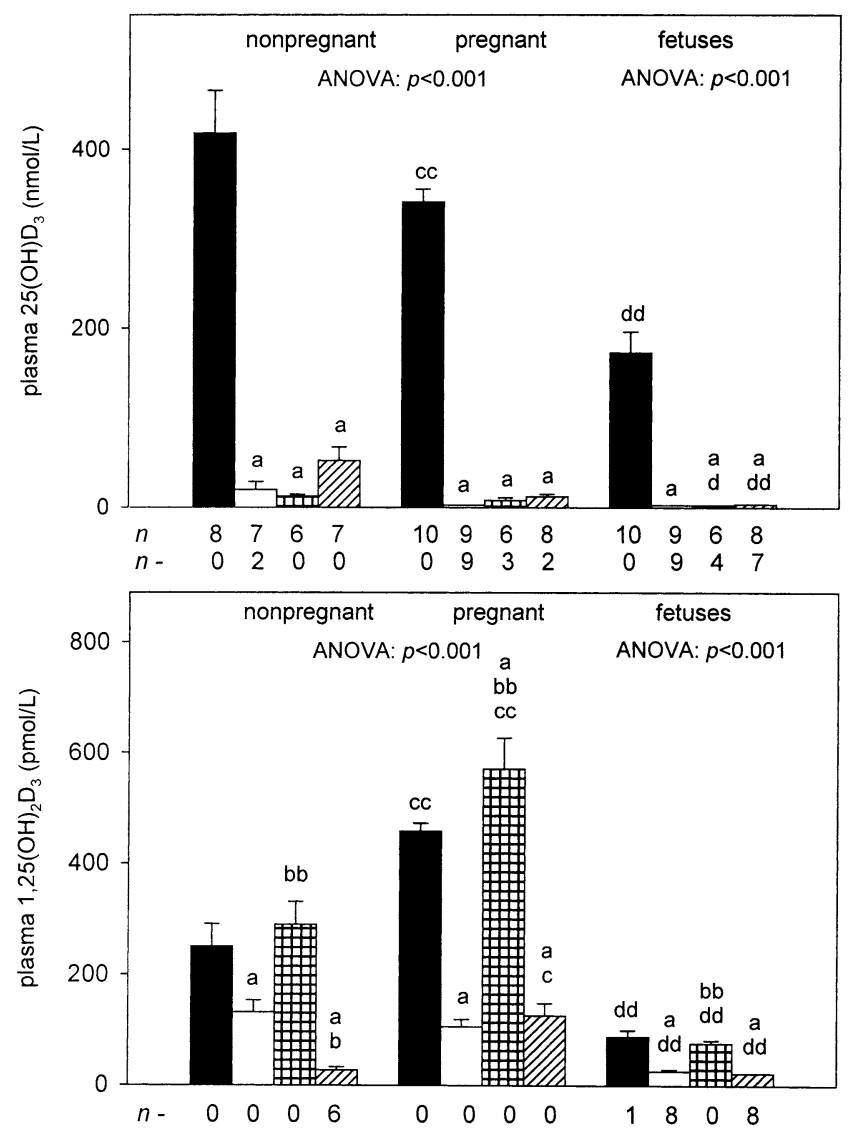

Fig. 1. Plasma concentrations of $25(\mathrm{OH}) \mathrm{D}_{3}$ and $1,25(\mathrm{OH})_{2} \mathrm{D}_{3}$ in nonpregnant, pregnant (day 57), and fetal guinea pigs. Groups: vitamin D-replete $(+\mathrm{D})$, black bars, vitamin D-deficient (-D), open bars, vitamin D-deficient with $1,25(\mathrm{OH})_{2} \mathrm{D}_{3}$ treatment $(-\mathrm{D}+1,25)$, squared bars; vitamin $\mathrm{D}$-deficient with lactose-, $\mathrm{Ca}-$, and $\mathrm{P}$-enriched diet $(-\mathrm{D}+\mathrm{Ca} / \mathrm{P})$, hatched bars. The number of data $(n)$ and the number of undetectable values $(n-)$ are shown. $25(\mathrm{OH}) \mathrm{D}_{3}$ levels were undetectable below 2.5 $\mathrm{ng} / \mathrm{mL}(6.25 \mathrm{nmol} / \mathrm{L})$, and $1,25(\mathrm{OH})_{2} \mathrm{D}_{3}$ levels were undetectable below $18 \mathrm{pg} / \mathrm{mL}(43 \mathrm{pmol} / \mathrm{L})$ : for data analysis, samples with undetectable $25(\mathrm{OH}) \mathrm{D}_{3}$ and $1,25(\mathrm{OH})_{2} \mathrm{D}_{3}$ were given a value of $1.25 \mathrm{ng} / \mathrm{mL}$ and $9 \mathrm{pg} / \mathrm{mL}$, respectively. Statistical analysis: a, significant difference with the respective (nonpregnant, pregnant, or fetal) $+\mathrm{D}$ group $(P<0.01)$; b, significant difference with the respective $-\mathrm{D}$ group (b: $P<0.05$, bb: $P<0.01)$, c, significant difference between pregnant vs. nonpregnant animals of the same diet group $(\mathbf{c}: P<0.05$, cc: $P<0.01$ ), d, significant difference between fetal vs. maternal values of the same diet group (d: $P<0.05$, dd: $P<0.01$ ).

magnification, in $11 \pm 0.3$ fields per section, corresponding to $51,436 \pm 2,689 \mu \mathrm{m}$ bone surface $(n=186)$.

The right tibia of adult animals was also processed for measurement of the tartrate-resistant acid phosphatase (TRAP)-positive bone surface. Tibiae were decalcified, embedded in methylmetacrylate and JB-4 kit (Polysciences, Warrington, PA) in a $1: 3$ ratio, and $4 \mu \mathrm{m}$ sections were obtained. TRAP staining was performed as described previously [34]. Measurements were performed in the metaphyseal secondary spongiosa as for OS/BS; the surface covered by TRAPpositive cells was denoted as TRAPS/BS.

\section{Data Analysis}

A software program was used (NCSS, Kaysville, UT). Adult (both nonpregnant and pregnant) and fetal data were first 
Table 1. Body weight, blood $\mathrm{Ca}^{2+}$, plasma phosphate (P), and osteocalcin (OC) levels in nonpregnant, pregnant, and fetal guineapigs
$+\mathrm{D}$
$-\mathrm{D}$
$-\mathrm{D}+1,25$
$-\mathrm{D}+\mathrm{Ca} / \mathrm{P}$
One-way ANOVA

\begin{abstract}
Body weight $(\mathrm{g})$
Nonpregnant

Pregnant

Fetuses
\end{abstract}

$\mathrm{Ca}^{2+}(\mathrm{nmol} / \mathrm{l})$

Nonpregnant

Pregnant

Fetuses

$P$ (mmol/1)

Nonpregnant

Pregnant

Fetuses

OC (nmol/1)

Nonpregnant

Pregnant

Fetuses

\begin{abstract}
762 (40)
$1168^{\mathrm{cc}}(39)$

$57.0(1.1)$
\end{abstract}

$1.39(0.03)$

$1.31(0.04)$

$1.52^{\mathrm{dd}}(0.04)$

$1.65(0.02)$

$1.68(0.02)$

$1.89^{\mathrm{dd}}(0.04)$

$7.3(0.5)$

$7.4(0.4)$

$62^{\mathrm{dd}}(3)$ $922^{\mathrm{a}}(42)$

$1073^{\mathrm{c}}$ (49)

$50.1^{\text {aa }}(1.1)$

$1.36(0.03)$

$1.31(0.03)$

$2.01^{\text {add }}(0.22)$

$1.62(0.04)$

$1.33^{\mathrm{aacc}}(0.01)$

$1.71^{\text {aadd }}(0.03)$

$7.8(0.6)$

$9.0(0.6)$

$48^{\text {aadd }}$ (3)
820 (49)

$1100^{\mathrm{cc}}(56)$

$47.8^{\text {aa }}(1.6)$

$1.42(0.02)$

$1.19^{\mathrm{abcc}}(0.02)$

$1.33^{\mathrm{bbd}}(0.05)$

$1.69(0.02)$

$1.58^{\mathrm{abbc}}(0.06)$

1.77 (0.10)

$9.7^{\mathrm{a}}(0.6)$

$9.2(1.3)$

$62^{\text {bbdd }}$ (4) $780^{\mathrm{b}}(40)$

$1152^{\mathrm{cc}}$ (24)

$54.5^{\mathrm{bb}}(1.0)$

$P<0.001$

$P<0.001$

$1.34(0.03)$

$1.35(0.04)$

$1.54^{\mathrm{b}}(0.13)$

$P=0.006$

$P=0.01$

$1.76^{\mathrm{abb}}(0.04)$

$1.57^{\text {aabbcc }}(0.03)$

$1.89^{\mathrm{bdd}}(0.02)$

$P<0.001$

$P=0.02$

$8.6(0.6)$

$7.2^{\mathrm{b}}(0.6)$

$61^{\text {bdd }}$ (3)
$P=0.04$

$P<0.001$

Number of data in each group as in Fig. 1 Statistical analysis: one-way ANOVA was carried out for adult (nonpregnant and pregnant) and for fetal guinea pigs separately, followed by Fisher's LSD multiple comparison test

${ }^{\mathrm{a}}$ Significant difference with the respective (nonpregnant, pregnant or fetal) $+\mathrm{D}$ group ${ }^{\mathrm{a}} P<0.05$, ${ }^{\text {aa }} P<0.01$ ); ${ }^{\mathrm{b}}$ Significant difference with the respective (nonpregnant, pregnant or fetal) -D group $\left({ }^{\mathrm{b}} P<0.05\right.$, $\left.{ }^{\mathrm{bb}} P<0.01\right)$; ${ }^{\mathrm{c}}$, Significant difference between pregnant group and the respective nonpregnant group $\left({ }^{\mathrm{c}} P<0.05,{ }^{\mathrm{cc}} P<0.01\right)$. Maternal-fetal differences for $\mathrm{Ca}^{2+}, \mathrm{P}$ and osteocalcin were examined by paired $t$ tests: ${ }^{\mathrm{d}}$ Significant difference between the fetuses and their mothers in the same group ( ${ }^{\mathrm{d}} P<$ $\left.0.05,{ }^{\mathrm{dd}} P<0.01\right)$

analyzed separately. One-way ANOVA was performed for each variable; if $P<0.05$, Fisher's LSD multiple comparison test was used to detect significant differences between individual groups at the $P<0.05$ and $P<0.01$ level. Blood/ plasma data of mothers and fetuses belonging to the same diet group were compared with paired $t$ tests.

\section{Results}

\section{Adult Guinea Pigs}

Plasma $25(\mathrm{OH}) \mathrm{D}_{3}$ concentrations were lower in pregnant than in nonpregnant $+\mathrm{D}$ guinea pigs (Fig. 1), confirming our previous data $[18,24] .25(\mathrm{OH}) \mathrm{D}_{3}$ was low or undetectable in guinea pigs fed the D-deficient $\operatorname{diet}(-\mathrm{D},-\mathrm{D}+1,25$, and $-\mathrm{D}+\mathrm{Ca} / \mathrm{P}$ groups); levels were more often undetectable in pregnant $(14 / 23)$ than in nonpregnant $(2 / 20)$ animals of these three groups. Plasma $1,25(\mathrm{OH})_{2} \mathrm{D}_{3}$ levels were significantly lower in nonpregnant and pregnant $-\mathrm{D}$ guinea pigs, compared with their respective + D-groups. $1,25(\mathrm{OH})_{2} \mathrm{D}_{3}$ treatment in $-\mathrm{D}$ animals restored $1,25(\mathrm{OH})_{2} \mathrm{D}_{3}$ toward levels comparable to (nonpregnant) or somewhat above (pregnant) those of $+\mathrm{D}$ animals. In contrast, $\mathrm{Ca} / \mathrm{P}$ supplementation further reduced $1,25(\mathrm{OH})_{2} \mathrm{D}_{3}$ levels in nonpregnant $-\mathrm{D}$ animals. During pregnancy, $1,25(\mathrm{OH})_{2} \mathrm{D}_{3}$ levels were raised in $+\mathrm{D},-\mathrm{D}+1,25$, and $-\mathrm{D}+\mathrm{Ca} / \mathrm{P}$, but not in $-\mathrm{D}$, guinea pigs. DBP levels were lower in the pregnant than in the respective nonpregnant groups (data not shown), confirming our previous data $[18,24]$. Changes in the free $1,25(\mathrm{OH})_{2} \mathrm{D}_{3}$ index between groups mirrored those of total $1,25(\mathrm{OH})_{2} \mathrm{D}_{3}$ levels (data not shown).

Body weight varied little: nonpregnant $-\mathrm{D}$ animals weighed more than $+\mathrm{D}$ and $-\mathrm{D}+\mathrm{Ca} / \mathrm{P}$ animals, but there was no such effect in pregnant guinea pigs (Table 1). $\mathrm{Ca}^{2+}$ levels were unchanged in $-\mathrm{D}$ animals, but pregnant guinea pigs in the $-D+1,25$ group had lower $\mathrm{Ca}^{2+}$ levels than $+\mathrm{D}$ or $-\mathrm{D}$ animals. Plasma $P$ levels were decreased in pregnant, but not nonpregnant $-D$ guinea pigs compared with the respective $+\mathrm{D}$ groups. $P$ levels were partly restored by both $1,25(\mathrm{OH})_{2} \mathrm{D}_{3}$ treatment and $\mathrm{Ca} / \mathrm{P}$ supplementation. Pearson correlation analysis of $25(\mathrm{OH}) \mathrm{D}_{3}, 1,25(\mathrm{OH})_{2} \mathrm{D}_{3}, \mathrm{Ca}^{2+}$, and $P$ levels showed that plasma $25(\mathrm{OH}) \mathrm{D}_{3}$ and $P$ levels were correlated $(r=0.58, P<0.001, n=61)$. There was no effect of a D-deficient diet on plasma osteocalcin concentrations.

Wet and dry weight of the femora were not different among groups (ANOVA: $P=0.39$ and $P=0.17$, respectively). On DXA analysis, the BMD of the left femur was lower in pregnant -D guinea-pigs, compared with pregnant $+\mathrm{D}$ and nonpregnant $-\mathrm{D}$ animals, and was normalized by $\mathrm{Ca} / \mathrm{P}$ supplementation (Fig. 2). Similar results were obtained for the right femur (ANOVA: $P=0.003$; data not shown). There was no significant difference in the BMD measured at a middiaphyseal area of the femur (ANOVA: $P=0.08$ and $P=0.18$ for the left and right femur, respectively), and in the BMD at a distal metaphyseal area $(P=0.08$ and $P=0.06$, respectively). On PQCT analysis, cortical bone 

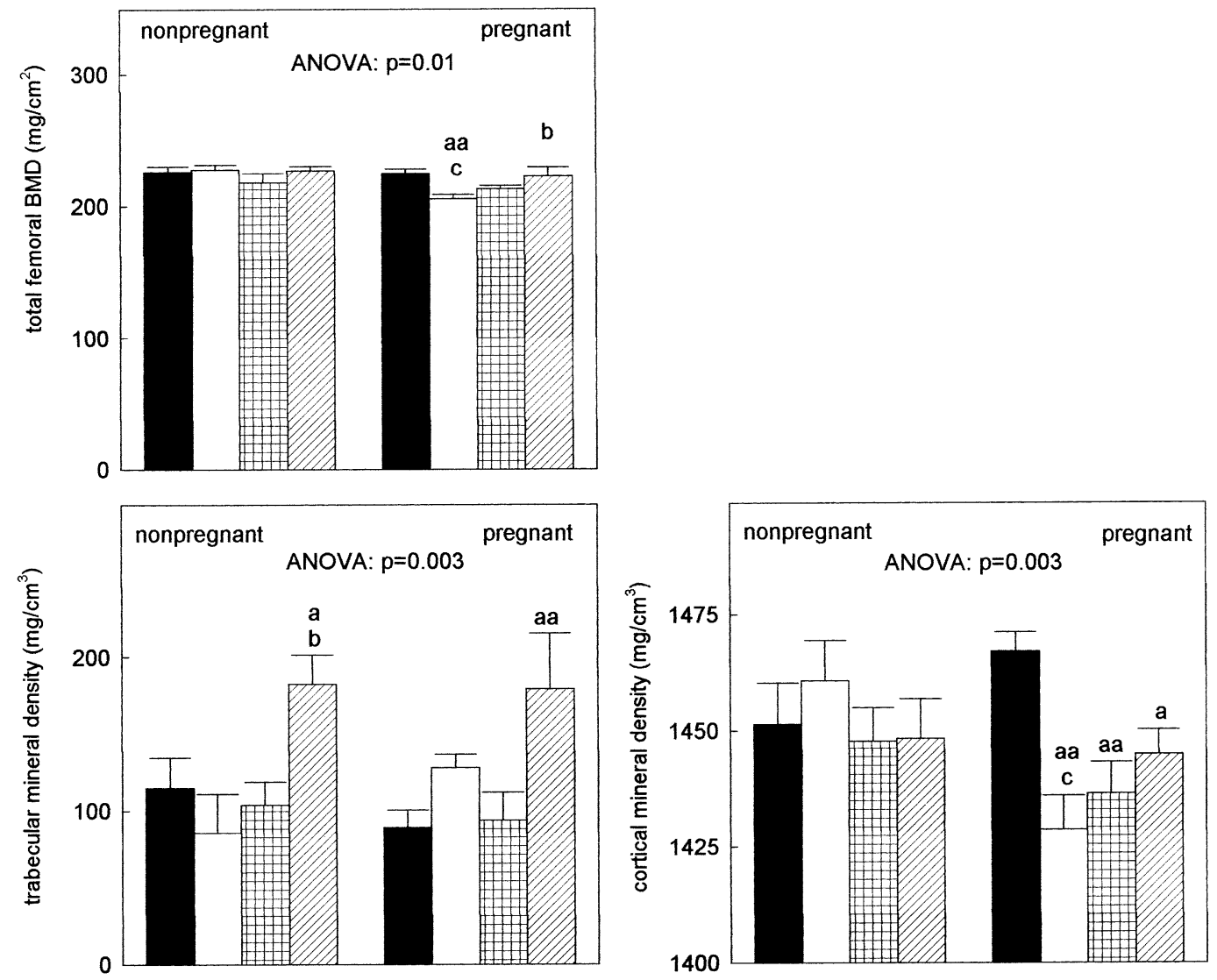

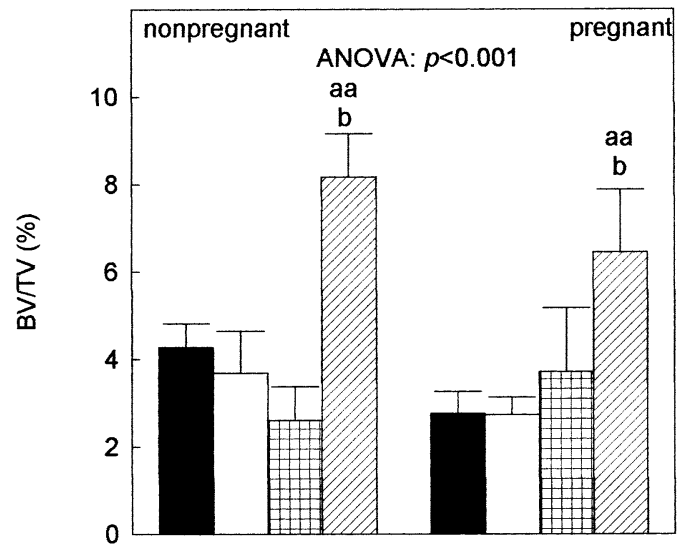

Fig. 2. Bone mass and bone density measurements in nonpregnant and pregnant guinea-pigs. Top: BMD of the whole left femur, measured by $D X A$. Middle: trabecular and cortical bone mineral density, assessed by $P Q C T$ at the distal femur. Bottom: trabecular bone volume (BV/TV), measured by histomorphometry at the secondary spongiosa of the proximal tibia. Groups and number of data in each group, as in Figure 1. Statistical analysis: a, significant difference with the respective (nonpregnant or pregnant) $+\mathrm{D}$ group $($ a: $P<0.05$, aa: $P$ $<0.01)$; $\mathbf{b}$, significant difference with the respective $-\mathrm{D}$ group (b, $P<0.01)$; c, significant difference with the nonpregnant - D group $(P<0.01)$. density was lower in pregnant $-\mathrm{D}$ than in pregnant $+\mathrm{D}$ or nonpregnant $-\mathrm{D}$ animals, but this was not reversed by $1,25(\mathrm{OH})_{2} \mathrm{D}_{3}$ treatment or $\mathrm{Ca} / \mathrm{P}$ supplementation. Trabecular bone density was not affected by the D-deficient diet, but $\mathrm{Ca} / \mathrm{P}$ supplementation increased trabecular bone density. Histomorphometry at the secondary spongiosa confirmed that trabecular bone volume was increased in guinea pigs in the $-\mathrm{D}+\mathrm{Ca} / \mathrm{P}$ group.
The growth plate width at the proximal tibia was higher in pregnant $-\mathrm{D}$ than in pregnant $+\mathrm{D}$ or nonpregnant $-\mathrm{D}$ guinea pigs, and was partly reversed by $1,25(\mathrm{OH})_{2} \mathrm{D}_{3}$ treatment and $\mathrm{Ca} / \mathrm{P}$ supplementation (Figs. 3, 4). Osteoid surface was lower in pregnant than in nonpregnant $+\mathrm{D}$ guinea pigs, confirming our previous observation [24]. -D animals had increased osteoid thickness and surface compared with $+\mathrm{D}$ 


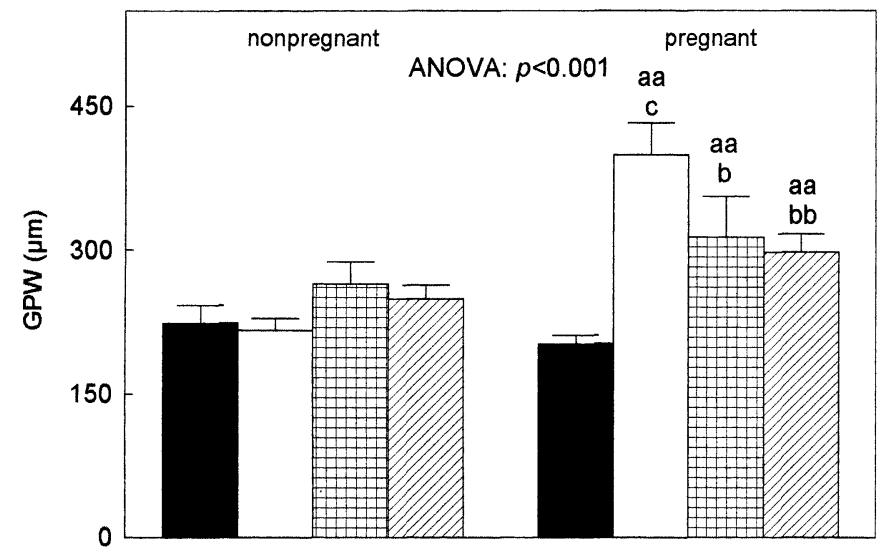

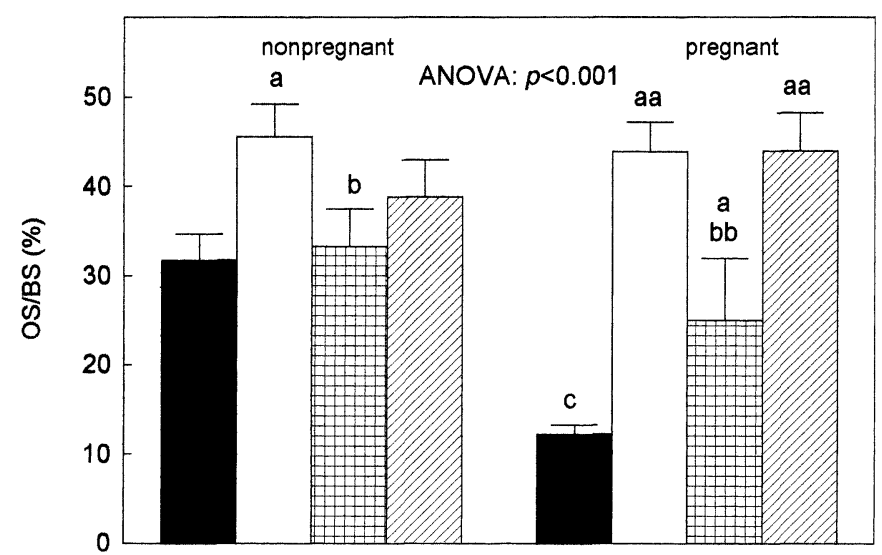

Fig. 3. Other histomorphometry data at the proximal tibia in nonpregnant and pregnant guinea pigs: GPW, growth plate width; OS/BS, osteoid surface; O.Th., osteoid thickness. Groups and number of data in each group, as in Figure 1. Statistical analysis: a, significant difference with the respective

animals, the difference being more robust in pregnant animals. $1,25(\mathrm{OH})_{2} \mathrm{D}_{3}$ treatment partly reversed the hyperosteoidosis of $-\mathrm{D}$ animals, but $\mathrm{Ca} / \mathrm{P}$ supplementation in $-\mathrm{D}$ animals failed to show a significant effect on osteoid surface and thickness. There was no difference among groups in the trabecular surface covered by TRAP-positive cells (ANOVA: $P=0.24$; data not shown). Dynamic morphometry at the secondary spongiosa confirmed that bone mineralization was markedly lower in pregnant animals of all groups (Fig. 5), again in line with our previous observation [24]. The $-\mathrm{D}$ diet did not affect mineral formation rate in nonpregnant guinea pigs, but accentuated the pregnancy-induced decline in mineral formation rate, so that mineral formation rate was lower in pregnant than in nonpregnant $-\mathrm{D}$ guinea pigs. This was the result of a lower mineralizing surface, whereas the mineral apposition rate was not affected by the Ddeficient diet. $\mathrm{Ca} / \mathrm{P}$ supplementation in $-\mathrm{D}$ animals suppressed the mineral formation rate compared with $+\mathrm{D}$ animals; in pregnant animals, the mineral formation rate of $-\mathrm{D}$ and $-\mathrm{D}+\mathrm{Ca} / \mathrm{P}$ guinea pigs was comparable.

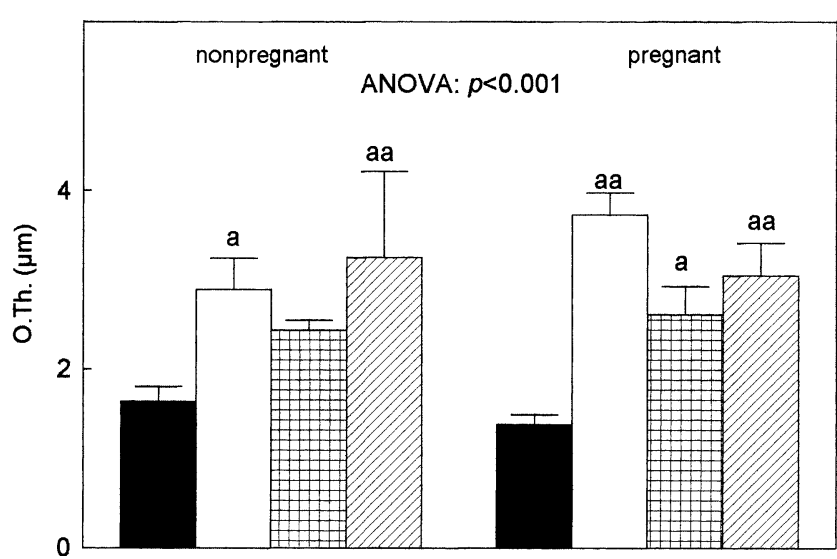

(nonpregnant or pregnant) $+\mathrm{D}$ group $($ a: $P<0.05$, aa: $P<$ 0.01 ); $\mathbf{b}$, significant difference with the respective (nonpregnant or pregnant) -D group (b: $P<0.05$, bb: $P<0.01$ ); c, significant difference with the respective $(-\mathrm{D}$ or $+\mathrm{D})$ nonpregnant group $(P<0.01)$.

\section{Fetal Guinea Pigs}

Litter size was $3.8 \pm 0.3$ in the $+\mathrm{D},-\mathrm{D}$, and $-\mathrm{D}+\mathrm{Ca} / \mathrm{P}$ groups and $5.0 \pm 0.6$ in the $-\mathrm{D}+1,25$ group (ANOVA: $P<0.001$, with a significant difference between the $-\mathrm{D}+1,25$ and both the $+\mathrm{D}$ and $-\mathrm{D}$ groups). Fetuses of $-\mathrm{D}$ guinea pigs weighed less than $+\mathrm{D}$ fetuses, which was reversed by $\mathrm{Ca} / \mathrm{P}$ supplementation, but not by $1,25(\mathrm{OH})_{2} \mathrm{D}_{3}$ treatment (Table 1). Placental weight was not significantly different among the groups (means between 3.9 and $4.1 \mathrm{~g}$; ANOVA: $P=0.73$ ).

Fetuses had higher levels of $\mathrm{Ca}^{2+}$ and $\mathrm{P}$ than their mothers, and maternal and fetal levels of $\mathrm{Ca}^{2+}(r=0.50$, $P=0.03, n=33)$ and phosphate $(r=0.72, P<0.001)$ were correlated. $-\mathrm{D}$ fetuses had higher $\mathrm{Ca}^{2+}$ but lower $\mathrm{P}$ levels than $+\mathrm{D}$ fetuses. Both $1,25(\mathrm{OH})_{2} \mathrm{D}_{3}$ treatment and $\mathrm{Ca} / \mathrm{P}$ supplementation in pregnant guinea pigs normalized fetal $\mathrm{Ca}^{2+}$ and $\mathrm{P}$ levels. Fetal osteocalcin levels were 8-fold higher than in their mothers; there was no significant correlation between maternal and fetal levels. Osteocalcin concentrations were lower in $-\mathrm{D}$ than in $+\mathrm{D}$ fetuses, and were restored to $+\mathrm{D}$ levels in $-\mathrm{D}+1,25$ and $-\mathrm{D}+\mathrm{Ca} / \mathrm{P}$ fetuses. There was no significant differ- 

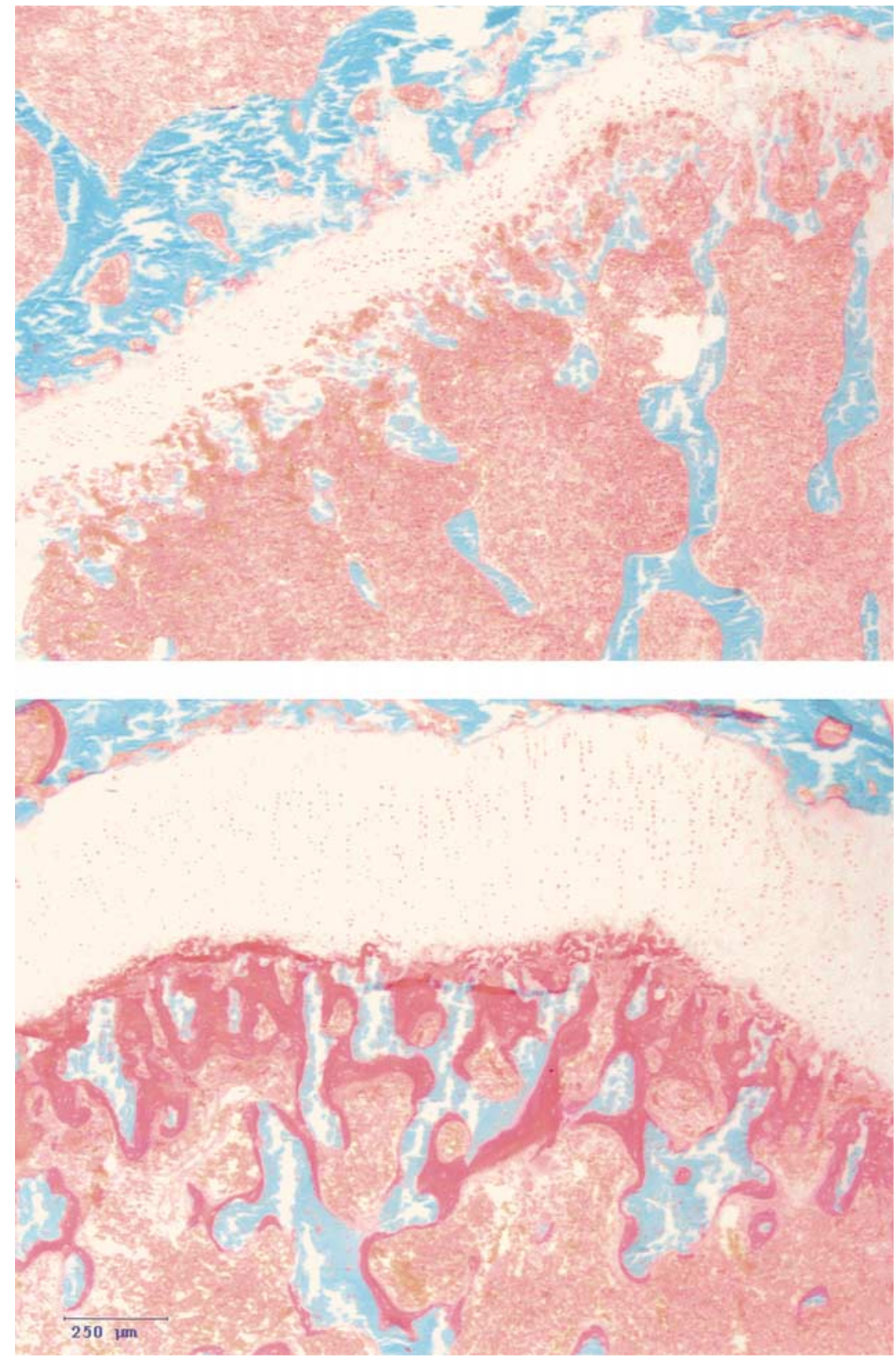

Fig. 4. Representative sections of the proximal tibia of a 57-day-old pregnant $+\mathrm{D}$ (top) and $-\mathrm{D}$ (bottom) guinea pig, demonstrating the wide growth plates and the marked increase in osteoid tissue. Modified Goldner trichrome, magnification $\times 65$. ence in amniotic fluid deoxypyridinoline concentrations among groups (ANOVA: $P=0.26$; data not shown).

Figure 1 shows that fetal $25(\mathrm{OH}) \mathrm{D}_{3}, \mathrm{DBP}$ and $1,25(\mathrm{OH})_{2} \mathrm{D}_{3}$ levels were lower than the respective maternal values, but the calculated free $1,25(\mathrm{OH})_{2} \mathrm{D}_{3}$ index was higher (data not shown). All $-\mathrm{D}$ fetuses had undetectable levels of $25(\mathrm{OH}) \mathrm{D}_{3}$, and $8 / 9$ had undetectable levels of $1,25(\mathrm{OH})_{2} \mathrm{D}_{3}$. $1,25(\mathrm{OH})_{2} \mathrm{D}_{3}$ treatment normalized $1,25(\mathrm{OH})_{2} \mathrm{D}_{3}$ levels. Maternal and fetal concentrations of the vitamin $\mathrm{D}$ metabolites were highly correlated $\left(r=0.85\right.$ for both $25(\mathrm{OH}) \mathrm{D}_{3}$ and free $1,25(\mathrm{OH})_{2} \mathrm{D}_{3}$ index and $r=0.65$ for $1,25(\mathrm{OH})_{2} \mathrm{D}_{3}$, all $P$ $<0.001, n=33)$
Whole-body BMC was reduced in -D fetuses compared with $+\mathrm{D}$ fetuses, which was restored to $+\mathrm{D}$ values by $1,25(\mathrm{OH})_{2} \mathrm{D}_{3}$ treatment and $\mathrm{Ca} / \mathrm{P}$ supplementation (Fig. 6). Because body weight was also lower in $-\mathrm{D}$ fetuses, the $\mathrm{BMC} /$ weight ratio was comparable in $-\mathrm{D}$ and $+\mathrm{D}$ fetuses. Since $-\mathrm{D}+1,25$ fetuses had normal $\mathrm{BMC}$ but reduced body weight, the $\mathrm{BMC} /$ weight ratio was higher than in $+\mathrm{D}$ and $-\mathrm{D}$ fetuses. Calculated fetal $\mathrm{BMD}$ values were comparable to $\mathrm{BMC}$ values (data not shown).

Histomorphometry of the proximal tibia showed that there was an expansion of the hypertrophic chondrocyte area in $-\mathrm{D}$ fetuses, which was normalized by both 

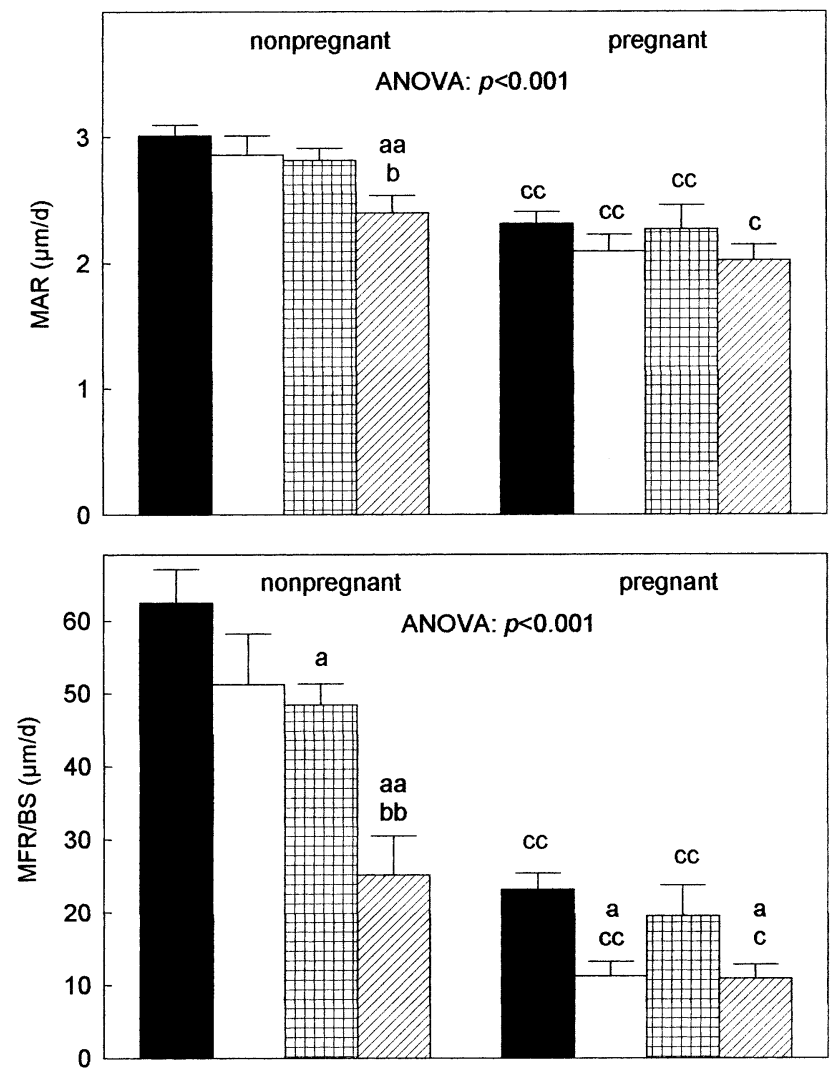

Fig. 5. Mineral apposition rate (MAR) and mineral formation rate $(\mathrm{MFR} / \mathrm{BS})$ at the proximal tibial metaphysis in nonpregnant and pregnant guinea pigs. Groups and number of data in each group, as in Figure 1. Statistical analysis: a, significant difference with the respective (nonpregnant or pregnant) $+\mathrm{D}$ group (a: $P<0.05$, aa: $P<0.01$ ); b, significant difference with the respective $-\mathrm{D}$ group (b: $P<0.05$, bb: $P<0.01$ ); c, significant difference between pregnant vs. nonpregnant animals in the same diet group (c: $P<0.05$, cc: $P<0.01$ ).

$1,25(\mathrm{OH})_{2} \mathrm{D}_{3}$ treatment and $\mathrm{Ca} / \mathrm{P}$ supplementation (Figs. 7 and 8). There was also a clear increase in the osteoid surface and thickness in $-\mathrm{D}$ fetuses, and this was partly reversed by $1,25(\mathrm{OH})_{2} \mathrm{D}_{3}$ treatment and $\mathrm{Ca} / \mathrm{P}$ supplementation.

\section{Discussion}

Guinea pigs fed the $-\mathrm{D}$ diet for 7-8 weeks had very low or undetectable $25(\mathrm{OH}) \mathrm{D}_{3}$ and significantly reduced $1,25(\mathrm{OH})_{2} \mathrm{D}_{3}$ levels. However, they were not hypocalcemic, presumably because of secondary hyperparathyroidism. We made three novel observations regarding the effects of $\mathrm{a}-\mathrm{D}$ diet in pregnant guinea pigs. The first was that the depletion in vitamin $\mathrm{D}$ metabolites engendered by the $-\mathrm{D}$ diet is more robust in pregnant animals: $25(\mathrm{OH}) \mathrm{D}_{3}$ levels were undetectable in all pregnant but in only $2 / 7$ nonpregnant guinea pigs, and the well-characterized rise in $1,25(\mathrm{OH})_{2} \mathrm{D}_{3}$ levels during pregnancy $[36,37]$ was absent in $-D$ animals. In
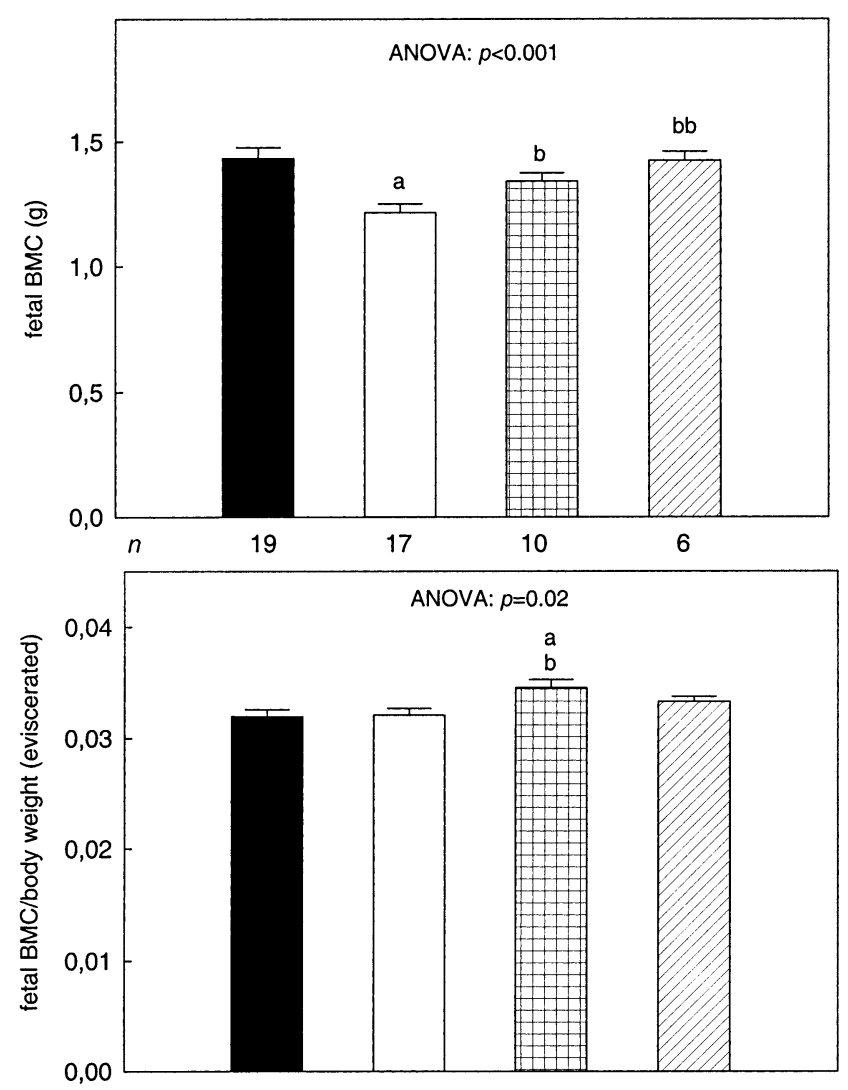

Fig. 6. Fetal whole-body BMC, assessed by $D X A$, and BMC per body weight (after evisceration post mortem). Groups as in Figure 1, $n$ is the number of data in each group. Statistical analysis: a, significant difference with $+\mathrm{D}$ fetuses $(P<0.01)$; b, significant difference with $-\mathrm{D}$ fetuses (b: $P<0.05$, bb: $P<$ $0.01)$.

addition, pregnant but not nonpregnant guinea pigs were hypophosphatemic.

The second observation was that the skeletal effects of the D-deficient diet are more dramatic during concurrent pregnancy. In nonpregnant guinea pigs, the only change was a modest rise in osteoid surface and thickness (osteomalacia). In counterpart, in pregnant animals, the $-\mathrm{D}$ diet induced (1) an increase in growth plate width (rickets), (2) a more robust increase in osteoid surface/thickness, (3) a dampening of the mineral formation rate, superimposed on the effect of pregnancy [24], and (4) a reduction in femoral BMD on DXA and in cortical bone density on PQCT. The pregnancy-induced skeletal effects are not surprising, given the substantial fetal $\mathrm{Ca} / \mathrm{P}$ needs in guinea pigs. Indeed, the $\mathrm{Ca}$ content of an average guinea pig litter at day 60 is $6 \mathrm{~g}$ [38], though we measured that femora of the nonpregnant guinea pigs in this series contain but $245 \pm 7 \mathrm{mg}$ $\mathrm{Ca}(n=6)$. By contrast, in rats, a $-\mathrm{D}$ diet for 3 weeks - resulting in very low or undetectable $25(\mathrm{OH}) \mathrm{D}_{3}$ but unaltered $1,25(\mathrm{OH})_{2} \mathrm{D}_{3}$ levels - did not affect pregnant animals differently than nonpregnant animals, although the endosteal bone formation rate was reduced only in pregnant rats [39]. 

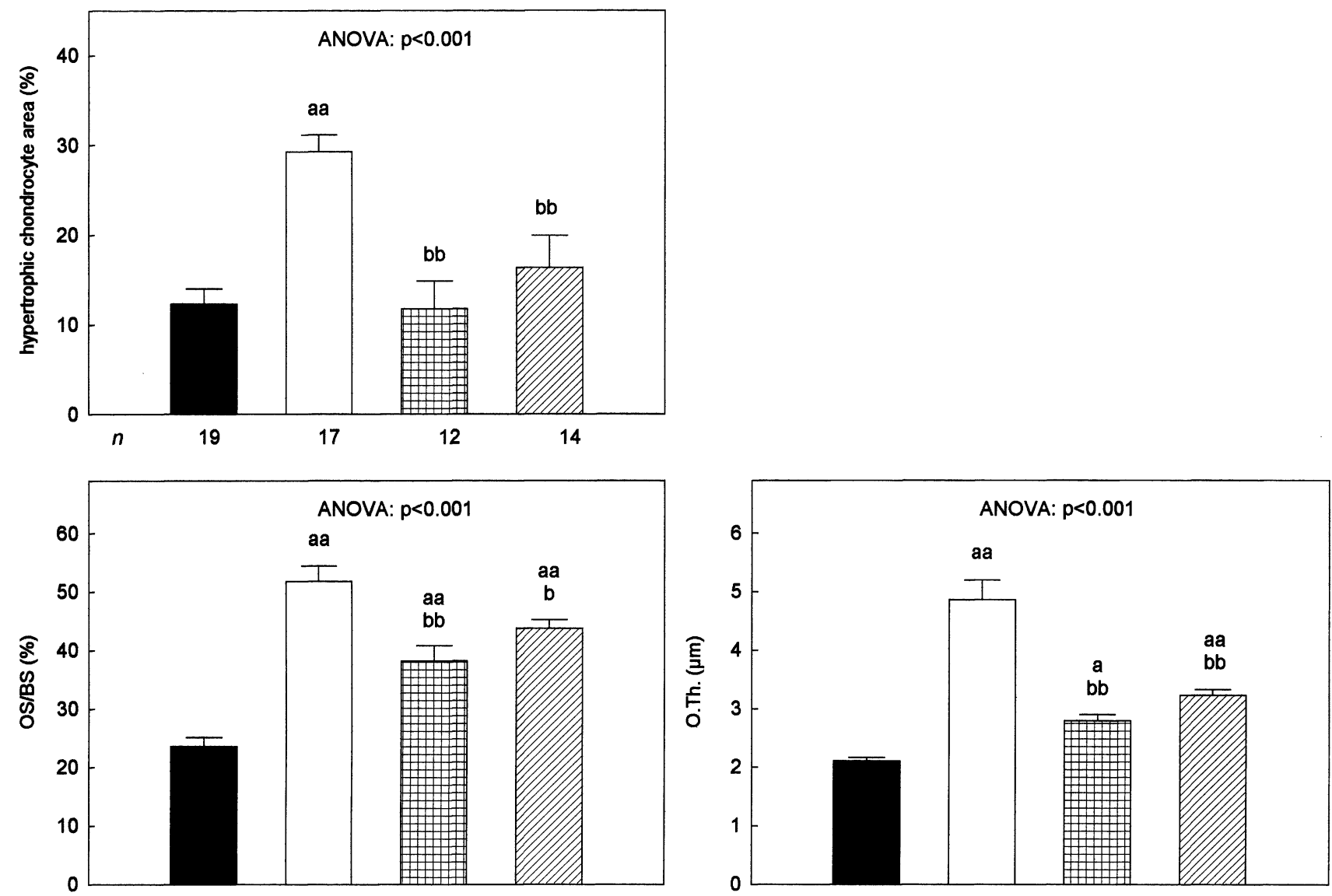

Fig. 7. Histomorphometry of the tibia in fetal guinea pigs: hypertrophic chondrocyte area (\% of total chondrocyte area) at the proximal tibial growth plate; OS/BS, osteoid surface; O.Th., osteoid thickness. Groups as in Figure 1, $n$ is the number of data in each group. Statistical analysis: a, significant difference with $+\mathrm{D}$ fetuses $(\mathbf{a}: P<0.05$, aa: $P<0.01)$; b, significant difference with - D fetuses (b: $P<0.05$, bb: $P<0.01)$.

These findings confirm some clinical observations. Fogelman et al. in Israel noted that D deficiency was clinically more apparent during pregnancy and breastfeeding [3]. Gannagé-Yared et al. found that high parity was a powerful predictor of low $25(\mathrm{OH}) \mathrm{D}_{3}$ levels in a cohort of 217 Lebanese women aged 30-50 years [5]. D deficiency was also common in Saudi-Arabian women in the reproductive period, and the BMD at both lumbar spine and proximal femur correlated inversely with parity [40].

The third observation was that fetuses of $-\mathrm{D}$ guinea pigs were growth-retarded, with a commensurate delay in bone mineralization. Indeed, plasma osteocalcin levels were reduced, and both weight and BMC were 10$15 \%$ lower, but BMC/weight was normal. These fetuses were unequivocally D-deficient: they had undetectable $25(\mathrm{OH}) \mathrm{D}_{3}$ and very low or undetectable $1,25(\mathrm{OH})_{2} \mathrm{D}_{3}$ levels. In addition, they were hypercalcemic and hypophosphatemic, indicative of secondary hyperparathyroidism. Hyperparathyroidism has also been observed in newborns of D-deficient Asian mothers [41]. Unfortunately, we were unable to actually measure PTH levels in these guinea pigs. Findings on bone histomorphometry mirrored those of their mothers: fetuses of D-deficient mothers had rickets (expansion of the hypertrophic cartilage zone) and osteomalacia (increased osteoid surface/thickness).

Subsequently, we infused nonpregnant, pregnant, and fetal $-\mathrm{D}$ guinea pigs with $1,25(\mathrm{OH})_{2} \mathrm{D}_{3}$, which corrected circulating $1,25(\mathrm{OH})_{2} \mathrm{D}_{3}$ to physiological or slightly supraphysiological levels. Although the same dose was given, we found that pregnant animals had higher plasma $1,25(\mathrm{OH})_{2} \mathrm{D}_{3}$ levels than nonpregnant animals. This suggests that the endogenous $1 \alpha$-hydroxylase activity was stimulated during pregnancy, as in D-replete animals. The observation that fetal $1,25(\mathrm{OH})_{2} \mathrm{D}_{3}$ levels were also normalized, corroborates the paradigm that circulating $1,25(\mathrm{OH})_{2} \mathrm{D}_{3}$ in fetuses is determined by transplacental transport rather than by synthesis in the fetal kidney. Indeed, this study and our previous studies in humans, guinea pigs, and rats demonstrate highly significant correlations between maternal and fetal circulating $1,25(\mathrm{OH})_{2} \mathrm{D}_{3}$ levels [2325]. Because the treatment was given for the last 4 weeks of pregnancy only, the maternal skeletal effects of $\mathrm{D}$ deficiency were partly normalized, with a re- 
ization of the growth plate width and osteoid surface/ thickness on morphometry and the cortical bone density on PQCT. Presumably, an even higher $\mathrm{Ca} / \mathrm{P}$ intake is required to completely reverse the effects of $\mathrm{D}$ deficiency during pregnancy. In their fetuses, the diet fully normalized growth, and several parameters of mineralization, including whole body BMC, plasma osteocalcin levels, and hypertrophic chondrocyte area. The data indicate that increasing the mineral supply to the mother largely reverses the effects of D deficiency on fetal growth and mineralization. Alternatively, the data strongly suggest that endogenous vitamin D metabolites per se are not necessary for fetal growth and mineralization in the guinea pig, and infer that the transplacental transport of $\mathrm{Ca}$ and $\mathrm{P}$ is largely - if not completely - vitamin D-independent. However, fetal osteoid surface/thickness was only partly normalized. It cannot, therefore, be excluded that vitamin D metabolites do modulate osteoblast function during fetal life: indeed, $1 \alpha$-hydroxylase gene and VDR expression have been demonstrated in fetal mouse and rat long bones, respectively $[43,44]$. Notwithstanding this possibility, the current study reaffirms previous evidence that the primary effect of $1,25(\mathrm{OH})_{2} \mathrm{D}_{3}$ during pregnancy consists of stimulating maternal intestinal $\mathrm{Ca}$ and $\mathrm{P}$ absorption, thus providing the fetus(es) with mineral supplies for bone mineralization in a hypercalcemic and hyperphosphatemic environment, while preventing significant bone demineralization as well as hypocalcemia and hypophosphatemia in the mother.

Acknowledgments. The authors thank H. Borghs, W. Coopmans, I. Jans, R. Janssens, R. Pijnenborg, and L. Vercruysse for their advice and help, and M. Op de Beeck for his help with animal care. K. Rummens received a grant ('Aspirant Navorser') from the Fonds voor Wetenschappelijk OnderzoekVlaanderen (Belgium).

\section{References}

1. Brooke OG, Brown IRF, Bone CDM, Carter ND, Cleeve HJW, Maxwell JD, Robinson VP, Winder SM (1980) Vitamin D supplements in pregnant Asian women: effects on calcium status and fetal growth. Br Med J 280:751-754

2. Taha SA, Dost SM, Sedrani SH (1984) 25-Hydroxyvitamin $\mathrm{D}$ and total calcium: extraordinarily low plasma concentrations in Saudi mothers and their neonates. Pediatr Res 18:739-741

3. Fogelman Y, Rakover Y, Luboshitzky R (1995) High prevalence of vitamin $\mathrm{D}$ deficiency among Ethiopian women immigrants to Israel: exacerbation during pregnancy and lactation. Isr J Med Sci 31:221-224

4. Atiq M, Suria A, Qamaruddin Nizami S, Ahmed I (1998) Maternal vitamin D-deficiency in Pakistan. Acta Obstet Gynecol Scand 77:970-973

5. Gannagé-Yared M-H, Chemali R, Yaacoub N, Halaby G (2000) Hypovitaminosis D in a sunny country: relation to lifestyle and bone markers. J Bone Miner Res 15:18561862

6. Henriksen C, Brunvand L, Stoltenberg C, Trygg K, Haug E, Pedersen JJ (1995) Diet and vitamin D status among Pakistani women in Oslo. Eur J Clin Nutr 49:211-218
7. Park W, Paust H, Kaufmann HJ, Offermann G (1987) Osteomalacia of the mother-rickets of the newborn. Eur $\mathbf{J}$ Pediatr 146:292-293

8. Brunvand L, Quigstad E, Urdal P, Haug E (1996) Vitamin D deficiency and fetal growth. Early Hum Dev 45:27-33

9. Marya RK, Rathee S, Dua V, Sangwan K (1988) Effect of vitamin D supplementation during pregnancy on fetal growth. Indian J Med Res 88:488-492

10. Namgung R, Tsang RC, Han D-G, Ho ML, Sierra RI (1998) Low total body bone mineral content and high bone resorption in Korean winter-bora versus summer-born newborn infants. J Pediatr 132:421-425

11. Halloran BP, DeLuca HF (1981) Effect of vitamin D deficiency on skeletal development during early growth in the rat. Arch Biochem Biophys 209:7-14

12. Miller SC, Halloran BP, DeLuca HF, Jee WSS (1983) Studies on the role of vitamin D in early skeletal development, mineralization, and growth in rats. Calcif Tissue Int 35:455-460

13. Brommage R, DeLuca HF (1984) Placental transport of calcium and phosphorus is not regulated by vitamin $\mathrm{D}$. Am J Physiol 246:F526-529

14. Mathews CHE, Brommage R, DeLuca HF (1986) Role of vitamin D in skeletal development in rats. Am $\mathbf{J}$ Physiol 250:E725-730

15. Li YC, Pirro AE, Amling M, Delling G, Baron R, Bronson $R$, Demay MB (1997) Targeted ablation of the vitamin D receptor: an animal model of vitamin D-dependent rickets type II with alopecia. Proc Natl Acad Sci USA 94:98319835

16. Yoshizawa T, Handa Y, Uematsu Y, Takeda S, Sekine K, Yoshihara Y, Kawakami T, Arioka K, Sato H, Uchiyama Y, Masushige S, Fukamizu A, Matsumoto T, Kato S (1997) Mice lacking the vitamin D receptor exhibit impaired bone formation, uterine hypoplasia and growth retardation after weaning. Nature Genet 16:391-396

17. Verhaeghe J, Thomasset M, Van Assche FA, Bouillon R (1990) Osteocalcin is vitamin D-dependent during the perinatal period in the rat. J Dev Physiol 14:311-317

18. Verhaeghe J, Allewaert K, Van Herck E, Van Bree R, Van Assche FA, Bouillon R (1994) 1,25-Dihydroxyvitamin $D_{3}$ and osteocalcin in maternal and fetal guinea pigs. Bone Miner 26:261-273

19. Halloran BP, DeLuca HF (1980) Effect of vitamin D deficiency on fertility and reproductive capacity in the female rat. J Nutr 110:1573-1580

20. Parfitt AM, Mathews CHE, Brommage R, Jarnagin K, DeLuca HF (1984) Calcitriol but no other metabolite of vitamin $\mathrm{D}$ is essential for normal bone growth and development. J Clin Invest 73:576-586

21. Gallagher JA, Beneton M, Harvey L, Lawson DEM (1986) Response of rachitic rat bones to 1,25-dihydroxyvitamin $\mathrm{D}_{3}$ : biphasic effects on mineralization and lack of effect on bone resorption. Endocrinology 119:1603-1609

22. Ron M, Levitz M, Chuba J, Dancis J (1984) Transfer of 25-hydroxyvitamin $\mathrm{D}_{3}$ and 1,25-dihydroxyvitamin $\mathrm{D}_{3}$ across the perfused human placenta. Am J Obstet Gynecol $148: 370-374$

23. Bouillon R, Van Assche FA, Van Baelen H, Heyns W, De Moor P (1981) Influence of the vitamin D-binding protein on the serum concentration of 1,25-dihydroxyvitamin $\mathrm{D}_{3}$. $\mathrm{J}$ Clin Invest 67:589-596

24. Rummens K, Van Herck E, van Bree R, Bouillon R, Van Assche FA, Verhaeghe J (2000) Dietary calcium and phosphate restriction in guinea-pigs during pregnancy: fetal mineralization induces maternal hypocalcaemia despite increased 1 1 ,25-dihydroxycholecalciferol concentrations. Br J Nutr 84:495-504

25. Verhaeghe J, Thomasset M, Bréhier A, Van Assche FA, Bouillon R (1988) $1,25(\mathrm{OH})_{2} \mathrm{D}_{3}$ and Ca-binding protein in fetal rats: relationship to the maternal vitamin $\mathrm{D}$ status. Am J Physiol 254:E505-512

26. Graham RW, Scothorne RJ (1970) Calcium homeostasis in the fetal guinea pig. Q J Exp Physiol 55:44-53 
27. Holtrop ME, Cox KA, Carnes DL, Holick MF (1986) Effects of serum calcium and phosphorus on skeletal mineralization in vitamin D-deficient rats. Am J Physiol 251:E234-240

28. Schaafsma G, Visser WJ, Dekker PR, Van Schaik M (1988) Effect of dietary calcium supplementation with lactose on bone in vitamin D-deficient rats. Bone 8:357-362

29. Li YC, Amling M, Pirro AE, Priemel M, Meuse J, Baron R, Delling G, Demay MB (1998) Normalization of mineral ion homeostasis by dietary means prevents hyperparathyroidism, rickets, and osteomalacia, but not alopecia in vitamin D receptor-ablated mice. Endocrinology 139:4391-4396

30. Amling M, Priemel M, Holzmann T, Chapin K, Rueger JM, Baron R, Demay MB (1999) Rescue of the skeletal phenotype of vitamin D receptor-ablated mice in the setting of normal ion homeostasis: formal histomorphometric and biomechanical analyses. Endocrinology 140:4982-4987

31. Verhaeghe J, van Bree R, Van Herck E, Jans I, Zaman Z, Bouillon R (1999) Calciotrophic hormones during experimental hypocalcaemia and hypercalcaemia in spontaneously diabetic rats. J Endocrinol 162:251-258

32. Bouillon R, Van Herck E, Jans I, Tan BK, Van Baelen H, De Moor P (1984) Two direct (nonchromatographic) assays for 25-hydroxyvitamin $\mathrm{D}_{3}$. Clin Chem 30:1731-1736

33. Verhaeghe J, Van Herck E, van Bree R, Bouillon R (1995) Effects of IGF-I, alone and in combination with $17 \beta-$ oestradiol, on bone remodelling parameters in ovariectomised rats. Growth Regul 5:210-217

34. Verhaeghe J, Oloumi G, Van Herck E, van Bree R, Dequeker J, Einhorn TA, Bouillon R (1997) Effects of longterm diabetes and/or high-dose $17 \beta$-estradiol on bone formation, bone mineral density, and strength in ovariectomized rats. Bone 20:421-428

35. Parfitt AM, Drezner M, Glorieux FH, Kanis JA, Malluche H, Meunier PJ, Ott SM, Recker RR (1987) Bone histo- morphometry: standardization of nomenclature, symbols, and units. J Bone Miner Res 2:595-610

36. Verhaeghe J, Bouillon R (1992) Calciotropic hormones during reproduction. J Steroid Biochem MolBiol 41:469477

37. Kovacs CS, Kronenberg HM (1997) Maternal-fetal calcium and bone metabolism during pregnancy, puerperium, and lactation. Endocr Rev 18:832-872

38. Engle WA, Lemons JA (1986) Composition of the fetal and maternal guinea pig throughout gestation. Pediatr Res 20:1156-1160

39. Marie PJ, Cancela L, Le Boulch N, Miravet L (1986) Bone changes due to pregnancy and lactation: influence of vitamin D status. Am J Physiol 251:E400-E406

40. Ghanman NN, Hammami MM, Bakheet SM, Khan BA (1999) Bone mineral density of the spine and femur in healthy Saudi females: relation to vitamin D status, pregnancy, and lactation. Calcif Tissue Int 65:23-28

41. Okonofua F, Menon RK, Houlder S, Thomas M, Robinson D, O'Brien S, Dandona P (1986) Parathyroid hormone and neonatal calcium homeostasis: evidence for secondary hyperparathyroidism in the Asian neonate. Metabolism 35:803-806

42. Symonds HW, Bubar RH, Crackel W, Twardock AR (1978) The effect of litter size on placental blood flow and placental calcium transfer in the multifoetate guinea-pig. Br J Nutr 39:347-356

43. Panda DK, Al Kawas S, Seldin MF, Hendy GN, Goltzman D (2001) 25-Hydroxyvitamin D 1 $\alpha$-hydroxylase: structure of the mouse gene, chromosomal assignment, and developmental expression. J Bone Miner Res 16:4656

44. Johnson JA, Grande JP, Roche PC, Kumar R (1996) Ontogeny of the 1,25-dihydroxyvitamin $D_{3}$ receptor in fetal rat bone. J Bone Miner Res 11:56-61 